\title{
Praktik pemberian makanan pendamping ASI (MP-ASI) bukan faktor risiko kejadian stunting pada anak usia 6-23 bulan
}

\author{
Complementary feeding practices were not risk factors of stunting among children 6-23 months
}

Hildagardis M.E. Nai' , I Made Alit Gunawan², Esti Nurwanti ${ }^{3}$

\begin{abstract}
Background: Stunting reflects a process of failure to reach linear growth potential as a result of suboptimal health or nutrition conditions. One of causal factors of stunting is inadequate of quality and quantity of complementary foods.

Objectives: To identify complementary feeding practices such as introduction age of complementarary foods, dietary diversity, and meal frequency as risk factors of stunting among children aged 6-23 months in Sedayu Subdistrict, Bantul, Yogyakarta.

Methods: Study design was case-control with ratio (1:1). The study used both quantitative methods as well as case control design and qualitative through interview. Cases were children aged 6-23 months who had length for age z-score <-2SD. Controls were children aged 6-23 months who had length for age z-score $\geq-2 S D$ who live adjacent to the case. Data were analyzed by using univariable (descriptive), bivariable (chi-square test), and multivariable analysis (multiple logistic regression).

Results: The result of bivariate analysis showed that introduction age of complementary foods (OR=1.07), dietary diversity $(O R=1.17)$, and meal frequency $(O R=1.69)$ were not risk factors of stunting. However, compared with high dietary diversity score, low dietary diversity score ( $\leq 2,3,4$ food groups) associated with increased odds of being stunted among children aged 6-23 months (OR=2.24, 95\% Cl:1.00-5.01, $O R=1.82,95 \% \mathrm{Cl}: 0.96-3.45, O R=1.66,95 \% \mathrm{Cl}: 0.81-3.46$ respectively). The result of multivariate analysis showed that mother's height $(O R=1.86)$ and story of low birth weight $(O R=3.23)$ were risk factors of stunting.

Conclusions: Complementary feeding practices such as age introduction of complementary foods, dietary diversity, and meal frequency were not risk factors of stunting among children aged 6-23 months. Mother's height and story of low birth weight were risk factors of stunting among children aged 6-23 months.
\end{abstract}

KEYWORDS: stunting, nutritional intake, nutritional status, complementary foods

\begin{abstract}
ABSTRAK
Latar belakang: Stunting merefleksikan kegagalan proses mencapai potensi pertumbuhan linear sebagai akibat dari kondisi kesehatan dan gizi yang tidak optimal. Salah satu penyebab kejadian stunting adalah kuantitas dan kualitas MP-ASI yang rendah.

Tujuan: Untuk mengidentifikasi risiko praktik pemberian MP-ASI seperti usia pengenalan MP-ASI, keragaman MP-ASI, dan frekuensi MP-ASI dengan kejadian stunting pada anak usia 6-23 bulan di Kecamatan Sedayu, Bantul, Yogyakarta.

Metode: Rancangan penelitian ini adalah kasus-kontrol dengan perbandingan 1:1 dan menggunakan pendekatan kuantitatif-kualitatif model concurrent embedded. Kasus adalah anak usia 6-23 bulan yang
\end{abstract}

\footnotetext{
1 Pasca Sarjana IImu Kesehatan Masyarakat Minat Gizi dan Kesehatan Fakultas Kedokteran Universitas Gadjah Mada, Jl. Farmako, Sekip Utara Yogyakarta 55281, e-mail: ni_mel@rocketmail.com

2 Program Studi Gizi dan Kesehatan, Fakultas Kedokteran Universitas Gadjah Mada. JI. Farmako, Sekip Utara, Yogyakarta 55281, e-mail: alitgunawan@gmail.com

${ }^{3}$ Program Studi S1 IImu Gizi, STIKES Alma Ata Yogyakarta, JI. Ring Road Barat Daya No 1, Yogyakarta 55183, e-mail: estinurwanti3@ gmail.com
} 
memiliki skor-z $P B / U<-2 S D$. Kontrol adalah anak usia 6-23 bulan yang memiliki skor-z $P B / U \geq-2 S D$ yang tinggal berdekatan dengan kelompok kasus. Analisis data menggunakan analisis univariat (deskriptif), bivariat (uji chi-square) dan multivariat (uji regresi logistik berganda).

Hasil: Analisis bivariat menunjukkan usia pengenalan MP-ASI $(O R=1,07)$, keragaman MP-ASI $(O R=1,17)$, dan frekuensi pemberian MP-ASI $(O R=1,69)$ bukan faktor risiko kejadian stunting $(p>0,05)$. Skor keragaman MP-ASl yang lebih rendah (kelompok makanan $\leq 2,3,4$ ) berhubungan dengan peningkatan risiko kejadian stunting berturut-turut $O R=2,24,95 \% \mathrm{Cl}: 1,00-5,01 ; \mathrm{O}=1,82,95 \% \mathrm{Cl}: 0,96-3,45$; OR=1,66, $95 \% \mathrm{Cl}: 0,81-3,46$. Analisis multivariat menunjukkan faktor risiko kejadian stunting adalah tinggi badan ibu $(O R=1,86)$ dan riwayat berat badan lahir rendah $(B B L R)(O R=3,23$,$) .$

Kesimpulan: Praktik pemberian MP-ASI seperti usia pengenalan, keragaman, dan frekuensi pemberian MP-ASI bukan merupakan faktor risiko kejadian stunting pada anak usia 6-23 bulan. Faktor risiko kejadian stunting pada anak usia 6-23 bulan yang bermakna adalah tinggi badan ibu dan riwayat BBLR.

KATA KUNCI: stunting, asupan makan, status gizi, MP-ASI

\section{PENDAHULUAN}

Masalah gizi kurang yang paling banyak diderita anak balita saat ini adalah masalah stunting (tubuh yang pendek). Stunting menjadi masalah utama kesehatan masyarakat di negara-negara berkembang dibandingkan underweight dan wasting $(1,2)$. Stunting merefleksikan kegagalan proses mencapai potensi pertumbuhan linear sebagai akibat dari kondisi kesehatan yang buruk dan gizi yang tidak optimal dalam kurun waktu yang lama $(3,4,5)$. Stunting memberikan dampak yang buruk bagi perkembangan fungsi kognitif anak sehingga mengakibatkan rendahnya produktivitas dan pendapatan di masa dewasa serta lebih rentan mengalami penyakit degeneratif (5-7).

Salah satu penyebab stunting adalah kuantitas dan kualitas MP-ASI yang rendah (5), selain kondisi kesehatan dan status gizi ibu yang buruk selama masa kehamilan, asupan zat gizi makro-mikro yang kurang, penyakit infeksi, ketidaktahanan pangan rumah tangga, sanitasi yang buruk, dan karakteristik sosio-demografi keluarga. Penelitian terdahulu menemukan ada hubungan yang signifikan antara usia pengenalan MP-ASI $(8,9)$ keragaman MPASI, dan frekuensi pemberian MP-ASI (10) dengan kejadian stunting. Tujuan penelitian ini adalah untuk mengetahui hubungan pola konsumsi MP-ASI dengan kejadian stunting pada anak usia 6-23 bulan di Kecamatan Sedayu, Bantul, Yogyakarta.

\section{BAHAN DAN METODE}

Jenis penelitian ini adalah observasional dengan rancangan kasus-kontrol menggunakan pendekatan kuantitatif-kualitatif model concurrent embedded. Penelitian ini merupakan bagian dari penelitian payung yang berjudul "Status Gizi Ibu Hamil dan Anak Bawah Dua Tahun (Baduta) di Kecamatan Sedayu, Kabupaten Bantul, Provinsi Daerah Istimewa Yogyakarta" yang dilaksanakan oleh Alma Ata Center for Healthy and Food (ACHEAF) Yogyakarta. Penelitian dilakukan Maret hingga Mei 2014. Populasi penelitian adalah anak usia 6-23 bulan di Kecamatan Sedayu yang berjumlah 853 orang. Subjek kasus adalah anak usia 6-23 bulan yang memiliki skor-z panjang badan menurut umur $(P B / U)<-2 S D$. Subjek kontrol adalah anak usia 6-23 bulan yang memiliki skor-z $\mathrm{PB} / \mathrm{U} \geq-2 \mathrm{SD}$ dan tinggal berdekatan dengan kasus. Pemilihan subjek penelitian berdasarkan kriteria inklusi yaitu bertempat tinggal tetap di wilayah Kecamatan Sedayu selama 6 bulan terakhir, orang tua atau wali anak mengizinkan anak untuk menjadi subjek penelitian selama penelitian berlangsung, sekaligus bersedia menjadi responden dengan menandatangani informed consent. Bila keluarga memiliki anak usia 6-23 bulan lebih dari satu orang, maka anak yang dijadikan sampel penelitian adalah anak yang lebih tua kecuali anak kembar diikutsertakan semuanya dalam penelitian. 
Jumlah kasus yang ditemukan adalah 138 orang. Dua belas orang dikeluarkan dari penelitian karena memenuhi kriteria eksklusi penelitian yaitu ibu dan atau ayah kandung telah meninggal dunia, anak tidak tinggal bersama ibu dan atau ayah kandung. Total kasus sebanyak 126 orang dan seluruhnya diambil (total sampling) sebagai subjek penelitian dengan pertimbangan bahwa selisih besar sampel dengan total kasus yang didapatkan di lapangan tidak jauh berbeda. Setelah kasus ditentukan, kontrol dipilih dengan syarat mempunyai usia yang sama dan bertempat tinggal dekat dengan kasus. Pemilihan informan untuk pengumpulan data kualitatif menggunakan metode purposive sampling. Praktik pemberian MP-ASI dinilai melalui wawancara individu dengan ibu kandung dari subjek penelitian. Pada ibu yang bekerja, pengumpulan data konsumsi makanan dilakukan dengan mewawancarai pengasuh anak.

Variabel bebas penelitian terdiri dari usia pengenalan MP-ASI, keragaman MP-ASI, dan frekuensi pemberian MP-ASI. Usia pengenalan MPASI adalah usia anak saat pertama kali diberikan makanan semi padat atau makanan padat. Usia pengenalan MP-ASI sesuai jika anak diberikan MPASI sejak usia 6 bulan. Usia pengenalan MP-ASI tidak sesuai jika anak diberikan MP-ASI pada usia $<6$ bulan atau $>6$ bulan. Berdasarkan perhitungan bulan penuh (11), interval usia 6 bulan adalah 6 bulan sampai dengan 6 bulan 29 hari. Keragaman MP-ASI dan frekuensi pemberian MP-ASI dinilai menggunakan indikator yang dikembangkan $\mathrm{WHO}$ (12) dan dimodifikasi pada waktu dan instrumen penggumpulan data. Keragaman MP-ASI adalah jumlah kelompok makanan yang dikonsumsi anak dalam sehari selama kurun waktu 3 bulan sebelum data penelitian dikumpulkan. Kelompok makanan untuk menilai keragaman terdiri dari 7 kelompok makanan yaitu: padi-padian atau umbi-umbian, daging-dagingan, dan organ-organ hewan lainnya, telur, kacang-kacangan atau polong-polongan, sayur-sayuran, buah-buahan sumber vitamin A, sayur dan buah lain serta susu atau produk susu (keju, yoghurt). Pemberian MP-ASI memenuhi minimum keragaman MP-ASI jika anak diberikan $\geq 4$ kelompok makanan dalam sehari. Pemberian
MP-ASI tidak memenuhi minimum keragaman MP-ASI jika bayi atau anak diberikan $<4$ kelompok makanan dalam sehari. Jumlah kelompok makanan dinyatakan dalam skor keragaman makanan. Skor keragaman makanan diperoleh dengan cara menjumlahkan kelompok makanan yang dikonsumsi sehari dari 7 jenis kelompok makanan yang telah disebutkan sebelumnya. Interval skor keragaman makanan dimulai dengan minimum 0 jika tidak ada kelompok makanan yang dikonsumsi sampai 7 jika semua kelompok makanan dikonsumsi. Kelompok makanan dikonsumsi harian bila setiap jenis atau salah satu jenis makanan dalam satu kelompok makanan dikonsumsi minimal sekali sehari. Bila setiap jenis makanan atau salah satu jenis makanan dalam satu kelompok makanan dikonsumsi mingguan atau bulanan atau dalam 3 bulan terakhir, maka penentuan kelompok makanan yang dikonsumsi harian diperoleh dengan cara menjumlahkan frekuensi konsumsi setiap jenis makanan dalam satu kelompok makanan kemudian dibagi dalam jumlah hari dalam satu minggu atau satu bulan atau dalam 3 bulan tergantung waktu frekuensi konsumsi. Kelompok makanan yang dimasukan dalam konsumsi harian bila dikonsumsi minimal sekali sehari.

Instrumen penelitian terdiri dari software Commcare ODK, kuesioner terstruktur yang dikembangkan oleh Alma Ata Center for Healthy and Food (ACHEAF), data pola konsumsi MP-ASI diukur dengan semi-quantitative food frequency questionnaire (SQ-FFQ) yaitu frekuensi konsumsi, data status gizi diperoleh dengan menentukan $P B / U$ yaitu dengan menganalisis grafik pada software WHO Anthro 2005, lengthboard dengan tingkat ketelitian $0,1 \mathrm{~cm}$ untuk mengukur panjang badan anak usia 6-23 bulan, microtoise dengan tingkat ketelitian $0,1 \mathrm{~cm}$ untuk menggukur tinggi badan ibu dan ayah, dan food models. Instrumen untuk penggumpulan data kualitatif adalah peneliti sendiri yang bertindak sebagai pewawancara, panduan wawancara, buku catatan, dan tape recorder. Sebelum proses pengumpulan data penelitian yang sesungguhnya, peneliti melakukan validasi dan reabilitas kuesioner terstruktur dan formulir SQ-FFQ dengan mewawancarai 30 orang ibu. 
Hasil wawancara jenis makanan yang dikonsumsi anak selama 3 bulan terakhir digunakan untuk menentukan daftar jenis-jenis makanan yang dikonsumsi anak-anak di Kecamatan Sedayu.

Analisis data kuantitatif terdiri dari analisis univariat (deskriptif), analisis bivariat dengan uji chi-square dan perhitungan OR dan $95 \%$ interval kepercayaan serta analisis multivariat dengan uji regresi logistik berganda. Analisis data menggunakan program Stata versi 12. Analisis data kualitatif dilakukan melalui wawancara semi terstruktur dan berlangsung secara terus-menerus sampai datanya jenuh (informan memberikan informasi yang hampir sama). Penelitian ini dilaksanakan setelah mendapatkan surat ethical clearance penelitian dari Komite Etik Fakultas Kedokteran Universitas Gadjah Mada nomor Ref: KE/FK/382/EC tahun 2014.

\section{HASIL}

\section{Karakteristik subjek penelitian}

Subjek penelitian berjumlah 252 orang yang tinggal di Kecamatan Sedayu dan memiliki karakteristik yang dapat dilihat pada Tabel 1. Sebagian besar subjek berjenis kelamin lakilaki $(55,2 \%)$ dengan ibu dan ayah yang memiliki pendidikan tinggi terdapat pada kelompok kasus $(66,7 \%$ dan $65,9 \%)$. Sebagian besar anak pada kelompok kasus memiliki ibu yang tidak bekerja $(65,1 \%)$. Pendapatan keluarga yang rendah dan tinggi pada kelompok kasus dan kontrol tidak jauh berbeda. Sebagian besar responden memiliki jumlah anggota keluarga lebih dari 4 orang yaitu pada kelompok kasus sebesar $78,6 \%$, sedangkan pada kelompok kontrol sebesar $77,0 \%$. Sebagian besar anak baik pada kelompok kasus $(61,1 \%)$ maupun kontrol $(61,9 \%)$ tidak diberikan ASI eksklusif. Anak yang tidak diberikan ASI lagi lebih banyak pada kelompok kontrol $(31,7 \%)$. Sebagian besar anak yang memiliki riwayat penyakit infeksi terdapat pada kelompok kasus $(63,5 \%)$. Ibu dan ayah dengan tinggi badan kurang lebih banyak pada kelompok kasus $(38,9 \%$ dan $36,5 \%)$ dibandingkan kelompok kontrol $(31,1 \%$ dan $30,2 \%)$. Anak yang memiliki riwayat berat badan lahir rendah lebih banyak pada kelompok kasus $(11,1 \%)$ dibandingkan kelompok kontrol $(4,0 \%)$.

Secara statistik, tidak ada perbedaan signifikan antara jenis kelamin, tingkat pendidikan ibu dan ayah, status pekerjaan ibu, tingkat pendapatan keluarga, jumlah anggota keluarga, riwayat ASI eksklusif, status pemberian ASI, tinggi badan ayah, dan riwayat penyakit infeksi antara kelompok kasus dan kontrol sedangkan pendapatan keluarga, tinggi badan ibu, dan riwayat BBLR memiliki perbedaan yang signifikan antara kelompok kasus dan kontrol. Anak yang berasal dari keluarga dengan pendapatan rendah memiliki risiko 1,7 kali lebih besar mengalami kejadian stunting dibandingkan anak yang berasal dari keluarga dengan pendapatan tinggi. Anak yang memiliki ibu dengan tinggi badan $<150 \mathrm{~cm}$ memiliki risiko 2 kali lebih besar mengalami kejadian stunting dibandingkan anak yang memiliki ibu dengan tinggi badan $\geq 150 \mathrm{~cm}$. Anak yang memiliki riwayat BBLR memiliki risiko 3 kali lebih besar mengalami stunting dibandingkan anak yang tidak memiliki riwayat BBLR.

Penilaian keragaman MP-ASI berdasarkan 7 kelompok makanan yang dikonsumsi harian menunjukkan tidak ada perbedaan konsumsi setiap kelompok makanan antara anak stunting dan tidak stunting (data tidak ditampilkan).

\section{Tingkatan usia pengenalan, frekuensi pemberian, dan keragaman MP-ASI}

Pada kelompok kasus dan kontrol, usia pengenalan MP-ASI sebagian besar terjadi pada usia 6 bulan $(59,5 \%$ dan $60,3 \%)$, makanan yang dikonsumsi tidak beragam (56,3\% dan $52,4 \%$ ), namun frekuensi pemberian MP-ASI tergolong cukup (84,9\% dan $90,5 \%)$. Berdasarkan hasil analisis, usia pengenalan MP-ASI, keragaman MP-ASI, dan frekuensi pemberian MP-ASI bukan merupakan faktor risiko kejadian stunting (Tabel 2)

Hasil analisis menunjukkan bahwa tidak ada tren linear yang signifikan antara tingkatan usia pengenalan MP-ASI dan frekuensi pemberian MP-ASI dengan risiko kejadian stunting ( $p$ untuk uji tren $>0,05$ ). Ada tren linear yang signifikan antara tingkatan skor keragaman MP-ASI dan 
Tabel 1. Karakteristik subjek penelitian pada kelompok stunting dan tidak stunting

\begin{tabular}{|c|c|c|c|c|c|c|c|c|}
\hline \multirow{2}{*}{$\begin{array}{c}\text { Karakteristik subjek } \\
\text { penelitian }\end{array}$} & \multicolumn{2}{|c|}{$\begin{array}{c}\text { Stunting } \\
\text { (Kasus) }\end{array}$} & \multicolumn{2}{|c|}{$\begin{array}{c}\text { Tidak stunting } \\
\text { (Kontrol) }\end{array}$} & \multicolumn{2}{|c|}{ Total } & \multirow[t]{2}{*}{ OR (95\% Cl) } & \multirow[t]{2}{*}{$\mathbf{p}$} \\
\hline & $\mathbf{n}$ & $\%$ & $\mathbf{n}$ & $\%$ & $\mathbf{n}$ & $\%$ & & \\
\hline \multicolumn{9}{|l|}{ Jenis kelamin anak } \\
\hline Laki-laki & 66 & 52,4 & 73 & 57,9 & 139 & 55,2 & $0,80(0,49-1,31)$ & 0,38 \\
\hline Perempuan & 60 & 47,6 & 53 & 42,1 & 113 & 44,8 & & \\
\hline \multicolumn{9}{|l|}{ Pendidikan ibu } \\
\hline Rendah & 42 & 33,3 & 46 & 36,5 & 88 & 34,9 & $0,87(0,52-1,46)$ & 0,60 \\
\hline Tinggi & 84 & 66,7 & 80 & 63,5 & 164 & 65,1 & 1 & \\
\hline \multicolumn{9}{|l|}{ Pendidikan ayah } \\
\hline Rendah & 43 & 34,1 & 46 & 36,5 & 89 & 35,3 & $0,90(0,54-1,51)$ & 0,69 \\
\hline Tinggi & 83 & 65,9 & 80 & 63,5 & 163 & 64,7 & 1 & \\
\hline \multicolumn{9}{|l|}{ Status pekerjaan ibu } \\
\hline Bekerja & 44 & 34,9 & 42 & 33,3 & 86 & 34,1 & $1,07(0,64-1,81)$ & 0,79 \\
\hline Tidak bekerja & 82 & 65,1 & 84 & 66,7 & 166 & 65,5 & 1 & \\
\hline \multicolumn{9}{|l|}{ Pendapatan keluarga } \\
\hline Rendah & 71 & 62,5 & 54 & 62,5 & 125 & 49,6 & $1,72(1,01-2,92)^{*}$ & 0,03 \\
\hline Tinggi & 55 & 63,5 & 72 & 63,5 & 127 & 50,4 & 1 & \\
\hline \multicolumn{9}{|l|}{ Jumlah anggota keluarga } \\
\hline$>4$ orang & 99 & 78,6 & 97 & 77,0 & 196 & 77,8 & $1,10(0,60-1,98)$ & 0,76 \\
\hline$\leq 4$ orang & 27 & 21,4 & 29 & 23,0 & 56 & 22,2 & 1 & \\
\hline \multicolumn{9}{|l|}{ Riwayat ASI eksklusif } \\
\hline Tidak ASI eksklusif & 77 & 61,1 & 78 & 61,9 & 155 & 61,5 & $0,97(0,58-1,61)$ & 0,90 \\
\hline ASI eksklusif & 49 & 38,9 & 48 & 38,1 & 97 & 38,5 & 1 & \\
\hline \multicolumn{9}{|l|}{ Status pemberian ASI } \\
\hline Tidak ASI & 29 & 23,0 & 40 & 31,7 & 69 & 27,4 & $0,64(0,37-1,12)$ & 0,12 \\
\hline Masih ASI & 97 & 77,0 & 86 & 68,3 & 183 & 72,6 & 1 & \\
\hline \multicolumn{9}{|l|}{ Riwayat penyakit infeksi } \\
\hline Ada & 80 & 63,5 & 75 & 59,5 & 150 & 59,5 & $1,22(0,74-2,02)$ & 0,44 \\
\hline Tidak ada & 46 & 36,5 & 51 & 40,5 & 97 & 38,5 & 1 & \\
\hline \multicolumn{9}{|l|}{ Tinggi badan ibu } \\
\hline$<150 \mathrm{~cm}$ & 49 & 38,9 & 30 & 31,3 & 79 & 31,1 & $2,04(1,18-3,51)$ * & 0,01 \\
\hline$\geq 150 \mathrm{~cm}$ & 77 & 61,1 & 96 & 76,2 & 173 & 68,7 & 1 & \\
\hline \multicolumn{9}{|l|}{ Tinggi badan ayah } \\
\hline$<162 \mathrm{~cm}$ & 46 & 36,5 & 38 & 30,2 & 84 & 33,3 & $1,33(0,79-2,25)$ & 0,29 \\
\hline$\geq 162 \mathrm{~cm}$ & 80 & 63,5 & 88 & 69,8 & 168 & 66,7 & 1 & \\
\hline \multicolumn{9}{|l|}{ Riwayat BBLR } \\
\hline BBLR & 14 & 11,1 & 5 & 4,0 & 19 & 7,5 & $3,0(1,06-8,67)$ * & 0,03 \\
\hline Normal & 112 & 88,9 & 121 & 96,0 & 233 & 92,5 & 1 & \\
\hline
\end{tabular}

* Signifikan $(p<0,05)$

risiko kejadian stunting ( $\mathrm{p}$ untuk tren $\mathrm{OR}<0,05$ ). Tren linear tersebut menunjukkan bahwa dengan adanya peningkatan jumlah kelompok makanan yang dikonsumsi anak dalam sehari menyebabkan adanya penurunan risiko kejadian stunting pada anak usia 6-23 bulan (Tabel 3).

Stratifikasi dilakukan untuk mengetahui OR pada setiap strata dan menduga status pemberian ASI merupakan confounder factor dan atau effect modifier terhadap risiko kejadian stunting atau bukan. Stratifikasi status pemberian ASI pada praktik pemberian MP-ASI (usia pengenalan MP-ASI dan keragaman MP-ASI) terhadap kejadian stunting dianalisis berdasarkan pertimbangan bahwa ASI merupakan salah satu penyumbang penting asupan energi dan zat gizi bagi pertumbuhan anak selain MP-ASI itu sendiri. Analisis stratifikasi status pemberian ASI pada hubungan frekuensi pemberian 
Tabel 2. Analisis bivariat praktik pemberian MP-ASI terhadap kejadian stunting

\begin{tabular}{|c|c|c|c|c|c|c|c|}
\hline \multirow{2}{*}{ Praktik pemberian MP-ASI } & \multicolumn{2}{|c|}{$\begin{array}{c}\text { Stunting } \\
\text { (Kasus) }\end{array}$} & \multicolumn{2}{|c|}{$\begin{array}{c}\text { Tidak stunting } \\
\text { (Kontrol) }\end{array}$} & \multicolumn{2}{|c|}{ Total } & \multirow[t]{2}{*}{ OR $(95 \% \mathrm{Cl})$} \\
\hline & $\mathbf{n}$ & $\%$ & $\mathbf{n}$ & $\%$ & $\mathbf{N}$ & $\%$ & \\
\hline \multicolumn{8}{|l|}{ Usia pengenalan MP-ASI } \\
\hline Tidak sesuai (< atau $>6$ bulan) & 51 & 40,5 & 50 & 39,7 & 101 & 40,1 & $1,07(0,65-1,76)$ \\
\hline Sesuai (6 bulan) & 75 & 59,5 & 76 & 60,3 & 151 & 59,9 & 1 \\
\hline \multicolumn{8}{|l|}{ Keragaman MP-ASI } \\
\hline Tidak beragam (<4 kelompok makanan) & 71 & 56,3 & 66 & 52,4 & 137 & 54,4 & $1,17(0,72-1,93)$ \\
\hline Beragam ( $\geq 4$ kelompok makanan) & 55 & 43,7 & 60 & 47,6 & 115 & 45,6 & 1 \\
\hline \multicolumn{8}{|l|}{ Frekuensi pemberian MP-ASI } \\
\hline Tidak cukup & 19 & 15,1 & 12 & 9,5 & 31 & 12,3 & $1,69(0,73-3,64)$ \\
\hline Cukup & 107 & 84.9 & 114 & 90,5 & 221 & 87,7 & 1 \\
\hline
\end{tabular}

Tabel 3. Tren linear risiko kejadian stunting untuk tingkatan praktik pemberian MP-ASI

\begin{tabular}{|c|c|c|}
\hline Praktik pemberian ASI & OR $(95 \% \mathrm{CI})$ & $\mathbf{p}$ \\
\hline \multicolumn{3}{|l|}{ Usia pengenalan MP-ASI } \\
\hline$\leq 3$ bulan & $1,00(0,36-2,81)$ & 1,00 \\
\hline 6 bulan & 1 & \\
\hline 4 bulan & $1,50(0,58-4,00)$ & 0,40 \\
\hline 6 bulan & 1 & \\
\hline 5 bulan & $0,71(0,38-1,34)$ & 0,29 \\
\hline 6 bulan & 1 & \\
\hline$>6$ bulan & $2,70(0,67-10,57)$ & 0,15 \\
\hline 6 bulan & 1 & \\
\hline Uji tren OR & & 0,96 \\
\hline \multicolumn{3}{|l|}{ Skor keragaman MP-ASI } \\
\hline$\leq 2$ kelompok makanan & $2,24(1,0-5,01)$ & 0,04 \\
\hline$\geq 5$ kelompok makanan & 1 & \\
\hline 3 kelompok makanan & $1,82(0,96-3,45)$ & 0,06 \\
\hline$\geq 5$ kelompok makanan & 1 & \\
\hline 4 kelompok makanan & $1,66(0,81-3,46)$ & 0,16 \\
\hline$\geq 5$ kelompok makanan & 1 & \\
\hline Uji tren OR & & $0,02^{*}$ \\
\hline \multicolumn{3}{|l|}{$\begin{array}{l}\text { Frekuensi pemberian MP- } \\
\text { ASI }\end{array}$} \\
\hline$\leq 2$ kali & $1,82(0,74-4,48)$ & 0,19 \\
\hline$>4$ kali & 1 & \\
\hline 3 kali & $1,13(0,61-2,10)$ & 0,70 \\
\hline$>4$ kali & 1 & \\
\hline 4 kali & $1,00(0,41-2,44)$ & 0,99 \\
\hline$>4$ kali & 1 & \\
\hline Uji tren OR & & 0,27 \\
\hline
\end{tabular}

* Signifikan $(p<0,05)$

MP-ASI dan kejadian stunting tidak dilakukan karena frekuensi pemberian ASI telah dibedakan antara anak yang masih ASI dan tidak ASI. Stratifikasi menggunakan analisis Mantel Haenzel ditunjukkan pada Tabel 4 dan Tabel 5.

Tabel 4 dan Tabel 5 menunjukkan bahwa ada perbedaan OR pada setiap strata. Hal tersebut berarti status pemberian ASI adalah effect modifier pada hubungan antara usia pengenalan MP-ASI dan keragaman MP-ASI dengan kejadian stunting. Hasil stratifikasi berdasarkan status pemberian ASI menunjukkan selisih adjusted OR (Mantel Haenzel OR) dan crude OR adalah sebesar 1,0\% untuk hubungan usia pengenalan MP-ASI dan kejadian stunting dan 4,8\% untuk hubungan keragaman MP-ASI dan kejadian stunting dan 4,8\%. Dengan demikian status pemberian ASI bukan counfounder factor hubungan usia pengenalan MP-ASI dan keragaman MP-ASI terhadap kejadian stunting.

Analisis multivariat dilakukan dengan uji regresi logistik berganda menggunakan permodelan dengan membandingkan nilai OR usia pengenalan MP-ASI, keragaman MP-ASI, dan frekuensi pemberian MP-ASI dengan kejadian stunting. Model dibangun menggunakan metode enter yaitu secara manual ditentukan variabel lain yang akan dikeluarkan dari analisis yaitu variabel lain yang tidak memiliki hubungan signifikan dengan kejadian stunting (nilai $p>0,05)$ (Tabel 6).

Model yang dipilih untuk memprediksi kejadian stunting adalah model 3 karena variabel lain yang tersisa (tinggi badan ibu dan riwayat BBLR) memiliki hubungan yang signifikan dengan kejadian stunting. Model 3 menunjukkan bahwa usia pengenalan MP-ASI, keragaman MP-ASI, dan frekuensi pemberian MP-ASI hanya mampu 
Tabel 4. Stratifikasi status pemberian ASI pada hubungan antara usia pengenalan MP-ASI dan kejadian stunting

\begin{tabular}{|c|c|c|c|c|c|c|c|}
\hline \multirow{2}{*}{$\begin{array}{c}\text { Status } \\
\text { pemberian ASI }\end{array}$} & \multirow{2}{*}{$\begin{array}{c}\text { Usia } \\
\text { pengenalan } \\
\text { MP-ASI }\end{array}$} & Stunting & $\begin{array}{c}\text { Tidak } \\
\text { stunting }\end{array}$ & \multirow[t]{2}{*}{ Total } & \multirow{2}{*}{$\begin{array}{l}\text { OR strata } \\
(95 \% \mathrm{Cl})\end{array}$} & \multirow{2}{*}{$\begin{array}{c}\text { Crude } \\
\text { OR }\end{array}$} & \multirow[t]{2}{*}{ M-H OR } \\
\hline & & $\mathrm{n}$ & $\mathrm{n}$ & & & & \\
\hline \multirow[t]{3}{*}{ Tidak ASI } & Tidak sesuai & 13 & 13 & 26 & \multirow{3}{*}{$\begin{array}{c}1,57 \\
(0,50-4,91)\end{array}$} & & \\
\hline & Sesuai & 14 & 22 & 36 & & & \\
\hline & Total & 27 & 35 & 62 & & 1,03 & 1,04 \\
\hline \multirow[t]{3}{*}{ Masih ASI } & Tidak sesuai & 38 & 37 & 75 & \multirow{3}{*}{$\begin{array}{c}0,91 \\
(0,49-1,70)\end{array}$} & $(0,61-1,77)$ & $(0,63-1,72)$ \\
\hline & Sesuai & 61 & 54 & 115 & & & \\
\hline & Total & 99 & 91 & 190 & & & \\
\hline
\end{tabular}

Tabel 5. Stratifikasi status pemberian ASI pada hubungan antara keragaman MP-ASI dan kejadian stunting

\begin{tabular}{|c|c|c|c|c|c|c|c|}
\hline $\begin{array}{c}\text { Status } \\
\text { pemberian ASI }\end{array}$ & $\begin{array}{c}\text { Keragaman } \\
\text { MP-ASI }\end{array}$ & $\begin{array}{c}\text { Stunting } \\
\mathrm{n}\end{array}$ & $\begin{array}{c}\text { Tidak stunting } \\
\mathrm{n} \\
\end{array}$ & Total & $\begin{array}{l}\text { OR strata } \\
(95 \% \mathrm{Cl})\end{array}$ & $\begin{array}{c}\text { Crude } \\
\text { OR }\end{array}$ & M-H OR \\
\hline \multirow[t]{3}{*}{ Tidak ASI } & Tidak beragam & 11 & 9 & 20 & 1,99 & & \\
\hline & Beragam & 16 & 26 & 42 & $(0,60-6,73)$ & & \\
\hline & Total & 27 & 35 & 62 & & 1,47 & 1,40 \\
\hline \multirow[t]{3}{*}{ Masih ASI } & Tidak beragam & 58 & 48 & 106 & 1,27 & $(0,87-2,48)$ & $(0,84-2,32)$ \\
\hline & Beragam & 41 & 43 & 84 & $(0,69-2,34)$ & & \\
\hline & Total & 99 & 91 & 190 & & & \\
\hline
\end{tabular}

memprediksi kejadian stunting sebesar 6,4\% setelah mengendalikan faktor tinggi badan ibu dan riwayat penyakit infeksi. Model 3 menunjukkan tidak ada hubungan yang signifikan antara usia pengenalan MP-ASI, skor keragaman MP-ASI, dan frekuensi pemberian MP-ASI dengan kejadian stunting. Tidak tampak tren linear usia pengenalan MP-ASI dan skor keragaman MP-ASI terhadap risiko kejadian stunting setelah mengendalikan faktor tinggi badan ibu dan riwayat penyakit infeksi. Berbeda dengan usia pengenalan MP-ASI dan skor keragaman MP-ASI, tampak ada tren linear frekuensi pemberian MP-ASI terhadap kejadian stunting tetapi tidak signifikan. Jadi, variabel yang memiliki hubungan yang signifikan dengan kejadian stunting adalah tinggi badan ibu dan riwayat berat badan bayi lahir rendah.

Hasil wawancara dengan beberapa informan memberikan data kualitatif sebagai berikut. Pada praktiknya, usia pengenalan MP-ASI dan frekuensi pemberian MP-ASI sudah sesuai rekomendasi kecuali praktik pemberian keragaman MP-ASI. Sebagian besar informan menyatakan bahwa MP-ASI diberikan kepada anak pada usia 6 bulan, frekuensi pemberian MP-ASI minimal 3 kali pemberian dalam sehari, dan pemberian MP-ASI kurang dari 4 kelompok makanan.

\section{BAHASAN}

Hasil analisis bivariat pada Tabel 1 menunjukkan bahwa ada hubungan yang signifikan antara pendapatan keluarga dan kejadian stunting. Pendapatan keluarga yang memadai akan menunjang tumbuh kembang anak karena orang tua dapat menyediakan semua kebutuhan anak baik yang primer seperti makanan maupun kebutuhan sekunder. Tingkat penghasilan juga ikut menentukan jenis pangan yang akan dibeli dengan adanya tambahan (13).

Hasil penelitian ini menunjukkan bahwa tidak ada hubungan yang signifikan antara usia pengenalan MP-ASI dan kejadian stunting pada anak usia 6-23 bulan. Pengenalan MP-ASI dini mempunyai efek yang kecil pada pertumbuhan anak tetapi jelas mempunyai efek negatif pada kesehatan anak (insiden penyakit diare) dan kemungkinan berpengaruh pada kelangsungan hidup anak (14). Tidak adanya hubungan antara pengenalan MP-ASI dan status gizi mungkin menggambarkan anak-anak 
Tabel 6. Model regresi logistik hubungan praktik pemberian MP-ASI dan kejadian stunting

\begin{tabular}{|c|c|c|c|}
\hline \multirow{2}{*}{ Variabel } & Model 1 & Model 2 & Model 3 \\
\hline & OR $(95 \% \mathrm{Cl})$ & OR $(95 \% \mathrm{Cl})$ & OR $(95 \% \mathrm{Cl})$ \\
\hline \multicolumn{4}{|l|}{ Usia pemberian MP-ASI } \\
\hline$\leq 3$ bulan & $0,86(0,30-2,47)$ & $1,03(0,35-3,01)$ & $1,00(0,35-2,91)$ \\
\hline 4 bulan & $1,46(0,55-3,91)$ & $1,36(0,49-3,76)$ & $1,44(0,53-3,93)$ \\
\hline 5 bulan & $0,68(0,35-1,29)$ & $0,32(0,32-1,21)$ & $0,62(0,32-1,21)$ \\
\hline 6 bulan & 1 & 1 & 1 \\
\hline$>6$ bulan & $2,72(0,68-10.93)$ & $2,53(0,62-10,34)$ & $2,76(0,68-11,24)$ \\
\hline \multicolumn{4}{|l|}{ Keragaman MP-ASI } \\
\hline$\leq 2$ kelompok makanan & $2,19(0,95-5,06)$ & $1,92(0,79-4,67)$ & $2,01(0,0,88-4,86)$ \\
\hline 3 kelompok makanan & $1,73(0,90-3,31)$ & $1,54(0,78-3,03)$ & $1,65(0,85-3,22)$ \\
\hline 4 kelompok makanan & $1,75(0,84-3,65)$ & $1,66(0,77-3,57)$ & $1,74(0,82-3,71)$ \\
\hline$\geq 5$ kelompok makanan & 1 & 1 & 1 \\
\hline \multicolumn{4}{|l|}{ Frekuensi pemberian MP-ASI } \\
\hline$\leq 2$ kali & $1,58(0,62-4,05)$ & $1,21(0,37-4,01)$ & $1,77(0,67-4,65)$ \\
\hline 3 kali & $1,12(0,58-2,15)$ & $0,87(0,33-2,28)$ & $1,26(0,64-2,48)$ \\
\hline 4 kali & $0,92(0,36-2,34)$ & $0,73(0,23-2,39)$ & $1,02(0,39-2,66)$ \\
\hline$>4$ kali & 1 & 1 & 1 \\
\hline \multicolumn{4}{|l|}{ Pendapatan keluarga } \\
\hline Rendah & & $1,30(0,74-2,28)$ & - \\
\hline Tinggi & & 1 & \\
\hline \multicolumn{4}{|l|}{ Status pemberian ASI } \\
\hline Tidak ASI & & $0,70(0,27-1,68)$ & - \\
\hline Masih ASI & & 1 & \\
\hline \multicolumn{4}{|l|}{ Tinggi badan ibu } \\
\hline$<150 \mathrm{~cm}$ & & $1,78(1,01-3,16)^{*}$ & $1,84(1,04-3,24)$ * \\
\hline$\geq 150 \mathrm{~cm}$ & & 1 & 1 \\
\hline \multicolumn{4}{|l|}{ Riwayat BBLR } \\
\hline BBLR & & $3,52(1,17-10,63)^{*}$ & $3,58(1,19-10,71)$ * \\
\hline BBLN & & 1 & 1 \\
\hline $\mathrm{N}$ & 252 & 252 & 252 \\
\hline $\mathrm{R} 2$ & 0,033 & 0,069 & 0,064 \\
\hline Goodness-of-fit test & 0,345 & 0,558 & 0,85 \\
\hline Area Under Curve (AUC) & 0,612 & 0,661 & 0,650 \\
\hline
\end{tabular}

*Signifikan $(p<0,05)$

yang lebih tua yang berumur 18-23 bulan karena kemungkinan efek negatif pemberian MP-ASI dini tidak berlangsung lama dan mungkin dimodifikasi oleh karakteristik pemberian makan lainnya (seperti keragaman MP-ASI dan frekuensi pemberian MPASI) dan kejadian penyakit (15). Pada penelitian ini, penilaian terhadap riwayat penyakit infeksi hanya berdasarkan pada gejala-gejala yang terjadi selama 2 minggu terakhir sebelum pengumpulan data penelitian sehingga efek pemberian MP-ASI dini terhadap kejadian penyakit infeksi tidak dapat digambarkan dengan pasti.
Hasil penelitian menunjukkan bahwa tidak ada hubungan yang signifikan antara waktu pengenalan MP-ASI dan kejadian stunting setelah mengendalikan variabel umur, tinggi badan ibu, dan riwayat BBLR. Hasil ini berbeda dengan penelitian lain karena diduga adanya faktor matching umur dalam penelitian ini. Perbedaan hasil penelitian ini dengan penelitian lain di Kota Yogyakarta (9) diduga karena faktor umur anak yang dikontrol dalam penelitian ini. Beberapa penelitian $(16,17)$ menunjukkan bahwa kejadian stunting meningkat dengan bertambahnya umur. Pada penelitian ini, 
matching umur dilakukan pada kasus dan kontrol sedangkan pada penelitian lain (9) tidak dilakukan matching umur. Hal tersebut terlihat pada hasil analisis multivariat yang menunjukkan tidak ada hubungan antara waktu pengenalan MP-ASI dan kejadian stunting setelah mengendalikan variabel umur, tinggi badan ibu, dan riwayat BBLR. Selain itu, pada penelitian ini, usia pengenalan MP-ASI adalah usia anak saat pertama kali diberikan makanan padat atau semi-padat sedangkan pada penelitian lain usia pengenalan MP-ASI dimulai saat pemberian makanan padat atau semi padat atau minuman (susu, air, teh, dan lain-lain) (9).

Berdasarkan hasil wawancara diketahui bahwa sebagian besar ibu memberikan MP-ASI kepada anak mereka pada usia 6 bulan. Hasil ini mendukung hasil analisis bivariat pada Tabel 2 yaitu usia pengenalan MP-ASI bukan merupakan faktor risiko kejadian stunting pada anak usia 6-23 bulan karena sebagian besar subjek penelitian diberikan makanan MP-ASI pada usia 6 bulan.

Analisis bivariat pada Tabel 2 menunjukkan bahwa tidak ada hubungan yang signifikan antara keragaman MP-ASI dan kejadian stunting pada anak usia 6-23 bulan. Tidak adanya hubungan antara keragaman MP-ASI dan kejadian stunting diduga karena tidak ada perbedaan konsumsi setiap kelompok makanan antara anak stunting dan tidak stunting seperti yang ditunjukkan dalam Tabel 2. Hasil penelitian lain di Nepal pada tahun 2010 menunjukkan ada hubungan yang signifikan antara minimum keragaman makanan dengan kejadian stunting pada anak balita (10). Hasil ini dapat berbeda karena penilaian terhadap kelompok makanan yang dikonsumsi menggunakan formulir recall $1 \times 24$ jam, sedangkan pada penelitian ini menggunakan formulir SQ-FFQ dengan interval waktu selama 3 bulan. Kurun waktu 3 bulan dianggap dapat menggambarkan kebiasaan makan anak.

Pada analisis tren linear (Tabel 3), skor keragaman makanan yang lebih rendah (kelompok makanan $\leq 2,3$, dan 4) dibandingkan dengan skor keragaman yang paling tinggi (kelompok makanan $\geq 5$ ) menghasilkan penurunan OR kejadian stunting yaitu secara berturut-turut sebesar 2,24,
1,82, dan 1,66. Hal tersebut mengindikasikan adanya penurunan risiko kejadian stunting dengan peningkatan jumlah kelompok makanan yang dikonsumsi oleh anak dalam sehari. Hasil penelitian ini sejalan dengan penelitian di Bangladesh pada tahun 2010 yang menunjukkan bahwa rendahnya keberagaman makanan merupakan prediktor yang kuat terhadap kejadian stunting (18).

Skor keragaman makanan dapat dijadikan indikator untuk menilai kecukupan asupan zat gizi makro (energi dan protein) (19-21) dan zat gizi mikro (22-24) pada anak-anak di negara berkembang. Penelitian di Kenya pada tahun 1988 (21), Afrika Selatan dan Filipina (22-24) menemukan hubungan positif yang kuat dan signifikan antara skor keragaman makanan dan asupan zat gizi pada anak-anak yang diberi ASI dan tidak ASI pada kelompok umur yang berbeda. Rata-rata asupan zat gizi meningkat dengan meningkatnya skor keragaman makanan. Zat gizi mikro yang diteliti pada penelitian-penelitian tesebut adalah vitamin A, vitamin C, tiamin, riboflavin, niasin, vitamin B6, vitamin B12, folat, seng, kalsium, dan zat besi. Penelitian di Filipina (22) menemukan tidak ada hubungan yang signifikan antara asupan kalsium dan vitamin B12 dengan skor keragaman makanan karena rendahnya konsumsi makanan hewani yang merupakan sumber yang baik dari kalsium dan vitamin B12.

Skor keragaman makanan juga secara signifikan berhubungan positif dengan status gizi anak berdasarkan indikator PB/U. Meskipun tidak ada konsistensi dalam rentang umur anak, banyak penelitian yang menunjukkan hubungan positif antara keragaman makanan dan skor-z PB/U. Peningkatan keragaman makanan berhubungan dengan skor $\mathrm{PB} / \mathrm{U}$ yang lebih tinggi antara anakanak usia 6-23 bulan $(19-21,25)$.

Stunting disebabkan oleh efek kumulatif dari rendahnya asupan zat gizi makro dan mikro selama periode yang lama ataupun hasil infeksi kronis (26). Skor keragaman makanan menggambarkan kualitas MP-ASI $(19,20,23)$. Kualitas MP-ASI sama pentingnya dengan kuantitas MP-ASI karena kualitas keragaman MP-ASI berhubungan dengan kepadatan zat gizi mikro dalam MP- 
ASI (27). Kualitas dan kuantitas MP-ASI dapat secara positif mempengaruhi pertumbuhan linear. Meningkatkan kuantitas MP-ASI tidak akan efektif bila tidak didukung oleh kualitas MP-ASI $(19,28)$. Zat gizi mikro yang penting untuk pertumbuhan dan berkaitan dengan kejadian stunting adalah zat besi, seng, tembaga, kalsium (29), dan vitamin A(3).

Hasil analisis kualitatif mendukung hasil analisis bivariat pada Tabel 2 yaitu secara keseluruhan konsumsi MP-ASI tidak beragam dalam sehari sehingga tidak ada hubungan antara keragaman MP-ASI dan kejadian stunting. Namun demikian, setelah mengelompokkan konsumsi yang tidak beragam tersebut dalam analisis tren linear, nampak ada penurunan risiko kejadian stunting dengan meningkatnya jumlah kelompok makanan yang dikonsumsi harian.

Hasil analisis bivariat pada Tabel 2 menunjukkan bahwa tidak ada hubungan yang signifikan antara minimum frekuensi pemberian MP-ASI dan kejadian stunting. Pada analisis multivariat (Tabel 6), tampak ada tren linear frekuensi pemberian MP-ASI terhadap kejadian stunting tetapi tidak signifikan. Meskipun demikian hal tersebut mengindikasikan adanya penurunan kejadian stunting dengan peningkatan frekuensi pemberian pemberian MP-ASI dalam sehari.

Penentuan cut off untuk kategori frekuensi pemberian makan dalam sehari diduga menjadi penyebab adanya perbedaan dalam hasil penelitian ini dan penelitian sebelumnya $(10,26)$. Pada penelitian terdahulu di Dodota-Sire, Ethiopia menyebutkan frekuensi pemberian MP-ASI dikategorikan menjadi $<3$ dan $\geq 3$ kali pemberian MP-ASI dalam sehari (26). Penelitian lainnya mengategorikan frekuensi pemberian MP-ASI menjadi $<4$ dan $\geq 4$ kali pemberian MP-ASI dalam sehari (10). Selain perbedaan cut off, tidak adanya hubungan antara frekuensi pemberian MP-ASI dan kejadian stunting diduga karena porsi yang tidak cukup dalam setiap kali pemberian MP. ASI. Meskipun pemberian MP-ASI dalam sehari sudah cukup, jumlah yang kecil tidak mampu memenuhi kecukupan energi dan zat gizi anak. Bayi memerlukan makanan tambahan selain ASI untuk memenuhi asupan energi dan zat gizi yang lain. Oleh karena itu, untuk mendapatkan energi atau zat gizi yang cukup, bayi harus diberi makanan dengan konsentrasi energi dan zat gizi yang tinggi atau diberi makanan lebih sering. Karena lambung bayi kecil, maka volume setiap kali makan harus tidak terlalu besar. Jadi, bayi atau anak harus makan lebih sering daripada orang dewasa (27). Kuantitas dan jenis makanan yang diberikan kepada anak dan frekuensi pemberian makan adalah faktor penting yang berhubungan dengan stunting. Anakanak yang mengonsumsi jumlah makanan yang relatif besar (>600 mL/hari) mempunyai skor PB/U yang lebih tinggi dibandingkan anak-anak dengan konsumsi yang kurang ( $<600 \mathrm{~mL} /$ hari). Anak-anak yang diberi makan $<3$ mangkok sedang $(<200 \mathrm{~mL})$ per hari mempunyai skor PB/U yang lebih rendah dibandingkan dengan anak-anak yang diberi makan $>3$ mangkok sedang (>200 mL). Oleh karena itu, konsumsi MP-ASI dengan jumlah yang kecil dan frekuensi yang kurang menjadi salah satu penyebab penting kejadian stunting (26).

Hasil wawancara dengan beberapa orang informan memberikan data kualitatif sebagai berikut. Pemberian MP-ASI kepada anak dalam sehari adalah minimal 3 kali pemberian. Meskipun jumlah tersebut dirasa cukup oleh sebagian besar informan, mereka menyatakan bahwa porsi yang mampu dihabiskan anak setiap kali pemberian makan sangat kurang. Hasil analisis kualitatif mendukung hasil analisis bivariat pada Tabel 3 yaitu frekuensi pemberian MP-ASI bukan merupakan faktor risiko kejadian stunting pada anak usia 6-23 bulan di Kecamatan Sedayu, Bantul, Yogyakarta. Ukuran porsi dan jumlah makanan yang dikonsumsi anak tidak diperhitungkan dalam penelitian ini.

Hasil analisis stratifikasi pada Tabel $\mathbf{4}$ dan Tabel 5 menunjukkan bahwa status pemberian ASI memodifikasi efek usia pengenalan MP-ASI terhadap kejadian stunting. Tabel 4 menunjukkan bahwa pemberian MP-ASI pada usia yang tidak sesuai pada anak yang tidak diberikan ASI lagi mempunyai risiko 1,6 kali lebih besar untuk mengalami kejadian stunting dibandingkan anakanak yang diberi MP-ASI pada usia yang sesuai. Pemberian MP-ASI pada usia yang tidak sesuai pada anak yang masih diberi ASI merupakan faktor 
proteksi bagi kejadian stunting. Anak-anak yang diberi MP-ASI dini mempunyai kemungkinan lebih besar untuk mengalami penyakit infeksi akibat praktik penyiapan MP-ASI yang kurang bersih dan kekurangan gizi akibat belum sempurnanya saluran pencernaan bayi untuk mencerna makanan. Pada kondisi tersebut, pemberian ASI diduga dapat mengurangi risiko bayi mengalami penyakit infeksi dan meningkatkan antibodi untuk melawan kuman penyakit di dalam tubuh. Selain itu, pemberian ASI pada usia dini masih menjadi sumber utama asupan energi dan zat gizi bayi. Sebaliknya, jika pada kondisi tersebut bayi tidak diberi ASI, risiko terpapar dengan kuman penyakit semakin tinggi dan kepadatan zat gizi dalam MP-ASI yang rendah tidak mampu mencukupi kebutuhan zat gizi bayi. Kedua kondisi tersebut mempengaruhi pertumbuhan bayi.

Tabel 5 menunjukkan bahwa pemberian MP-ASI yang tidak beragam pada anak yang tidak diberikan ASI lagi mempunyai risiko 2 kali untuk mengalami kejadian stunting dibandingkan anakanak yang diberi MP-ASI beragam. Pemberian MP-ASI yang tidak beragam pada anak yang masih diberikan ASI mempunyai risiko 1,3 kali lebih besar untuk mengalami kejadian stunting dibandingkan anak-anak yang yang diberi MP-ASI yang beragam. Hasil penelitian ini menunjukkan adanya penurunan risiko kejadian stunting dengan adanya pemberian ASI pada anak-anak yang diberi MP-ASI yang tidak beragam. Penelitian terdahulu di Lima, Peru menemukan bahwa pada anak-anak berusia 12-15 bulan dengan asupan produk hewani yang rendah, pemberian ASI berhubungan positif dan signifikan dengan pertumbuhan linear. Salah satu penyumbang penting energi dan zat gizi untuk asupan zat gizi anak adalah ASI. Selain sumbangan langsung terhadap asupan energi dan zat gizi, ASI mungkin memodifikasi efek pemberian MP-ASI pada pertumbuhan linear dengan menyiapkan komponen zat gizi yang rendah dalam MP-ASI (30). Terkait hubungan skor keragaman makanan dan pertumbuhan linear, hubungan yang kuat antara skor keragaman makanan dan skor-z TB/U (tinggi badan/umur) ditemukan pada anak-anak yang tidak lagi diberikan ASI dibandingkan yang masih ASI karena pemenuhan zat gizi dari anak- anak tersebut hanya bergantung pada pemberian MP-ASI (19). Penelitian lain di Kenya menemukan bahwa tidak ada perbedaan yang signifikan berdasarkan status pemberian ASI antara status ASI dan level keragaman (20). Anak-anak yang masih ASI mengonsumsi makanan dengan keragaman yang terbatas dikarenakan lebih banyak ASI (18). Berdasarkan hasil penelitian ini, status pemberian ASI menurunkan risiko kejadian stunting pada hubungan antara usia pengenalan MP-ASI dan kejadian stunting serta hubungan keragaman makanan dan kejadian stunting meskipun tidak signifikan. Oleh karena itu, meskipun penelitian terdahulu menunjukkan hasil yang beragam terhadap efek pemberian ASI pada pertumbuhan, anak-anak sebaiknya terus diberikan ASI sampai anak berusia 2 tahun sesuai rekomendasi WHO.

Hasil analisis multivariat (Tabel 6) menunjukkan bahwa tinggi badan ibu dan riwayat BBLR berhubungan signifikan dengan kejadian stunting pada anak setelah mengontrol variabel praktik pemberian MP-ASI, status ASI, dan tinggi badan ibu. Tinggi badan ibu $<150 \mathrm{~cm}$ adalah faktor risiko kejadian stunting pada anak yang dilahirkan. Anak yang lahir dari ibu dengan tinggi badan $<150 \mathrm{~cm}$ mempunyai risiko mengalami kejadian stunting 1,9 kali lebih besar daripada anak yang lahir dari ibu dengan tinggi badan $\geq 150 \mathrm{~cm}$. Hubungan tinggi badan ibu dan kesehatan bayi dapat dilihat dari dua faktor yaitu faktor keturunan dan faktor kesehatan ibu. Salah satu atau kedua orang tua yang pendek akibat kondisi patologi (seperti defisiensi hormon pertumbuhan) memiliki gen dalam kromosom yang membawa sifat pendek. Kondisi tersebut memperbesar peluang anak mewarisi gen tersebut dan tumbuh menjadi anak pendek. Akan tetapi, bila orang tua pendek akibat kekurangan zat gizi atau penyakit, kemungkinan anak dapat tumbuh dengan tinggi badan normal selama anak tersebut tidak terpapar faktor risiko lain (31). Wanita pendek mempunyai tulang pinggul yang lebih sempit. Pada ibu hamil yang pendek terjadi hambatan aliran darah dalam kandungan karena kondisi tersebut sehingga pertumbuhan uterus, plasenta, dan janin pun terhambat (7).

Riwayat BBLR merupakan faktor risiko kejadian stunting. Bayi yang lahir dengan BBLR 
mempunyai risiko mengalami kejadian stunting 3 kali lebih besar daripada bayi yang lahir dengan berat badan normal. Ibu yang mengalami gizi kurang saat konsepsi dan selama masa kehamilan berpengaruh buruk terhadap pertumbuhan awal janin dan dapat menjadi faktor risiko stunting pada bayi dan anak-anak (3). Jika janin di dalam kandungan mengalami gizi kurang, janin segera merespon dengan cara menggunakan cadangan makanan untuk menghasilkan energi bagi pertumbuhannya. Jika terus mengalami gizi kurang, kecepatan pertumbuhannya akan melambat. Jika zat gizi dipenuhi kembali setelah beberapa hari, kecepatan pertumbuhan akan kembali seperti sebelumnya tetapi gizi kurang yang lama menyebabkan pertumbuhan melambat secara permanen (32).

Penelitian ini memiliki beberapa kelemahan. Desain penelitian kasus-kontrol yang digunakan dalam penelitian ini menyebabkan perolehan data pajanan terhadap faktor risiko diperoleh dengan mengandalkan daya ingat responden. Daya ingat responden ini menyebabkan data yang diperoleh sukar dibuktikan keakuratannya. Penentuan minimum frekuensi pemberian MP-ASI tidak memperhitungkan jumlah setiap jenis makanan yang dikonsumsi bayi. Penilaian penyakit infeksi hanya dalam waktu yang singkat yaitu berdasarkan adanya gejala-gejala penyakit infeksi dalam dua minggu terakhir sehingga tidak mampu menilai dampak penyakit infeksi pada anak-anak yang diberi MP-ASI dini.

\section{KESIMPULAN DAN SARAN}

Praktik pemberian MP-ASI bukan merupakan faktor risiko kejadian stunting pada anak usia 6-23 bulan. Akan tetapi, peningkatan jumlah kelompok makanan yang dikonsumsi dalam sehari dapat menurunkan risiko kejadian stunting pada anak usia 6-23 bulan. Tinggi badan ibu dan riwayat BBLR merupakan faktor risiko kejadian stunting pada anak usia 6-23 bulan di Kecamatan Sedayu, Bantul, Yogyakarta. Praktik pemberian MP-ASI terkait usia pengenalan MP-ASI dan frekuensi pemberian MP-ASI sudah sesuai rekomendasi kecuali praktik pemberian keragaman MP-ASI. Sebagian besar informan menyatakan bahwa pemberian MPASI kepada anak pada usia 6 bulan, frekuensi pemberian MP-ASI minimal 3 kali, dan pemberian MP-ASI kurang dari 4 kelompok makanan.

Pemerintah daerah setempat secara berkelanjutan mendorong pemberdayaan masyarakat untuk penganeka-ragaman pangan melalui program pengembangan kebun-kebun keluarga. Pemerintah juga diharapkan dapat membantu dalam pengadaan bibit dan pelatihan bagi pengelolaan lahan. Dinas Kesehatan Kabupaten Bantul diharapkan dapat membuat program intervensi gizi bagi ibu hamil risiko tinggi termasuk ibu dengan tinggi badan kurang dalam bentuk skrining ibu hamil risiko tinggi untuk selanjutnya diberikan pemahaman seputar kondisi kesehatan mereka dan pemberian informasi seputar gizi selama masa kehamilan. Selain itu, ibuibu hamil risiko tinggi dapat diberikan suplementasi zat gizi. Intervensi gizi bagi anak usia 6-23 bulan dalam bentuk sosialisasi pedoman gizi seimbang (PGS) yang terbaru kepada ibu-ibu pada jadwal posyandu.

\section{RUJUKAN}

1. UNICEF. Tracking progress on child and maternal nutrition: a survival and development priority. New York: UNICEF; 2009.

2. De Onis M, Blossner M, Borghi E. Prevalence and trends of stunting among pre-school children, 1999-2220. Public Health Nutr. 2011;32:1-7.

3. Allen LH, Gillespie SR. What works ? A review of the efficacy and effectiveness of nutrition interventions. Manila: The Asian Development Bank; 2001.

4. Dewey KG, Begum K. Why stunting matters [Internet]. Alive\&thrive technical brief. 2010 [cited 2013 Apr 25]. p. 1-7. Available from: http:// www.aliveandthrive.org/sites/default/files/Brief 2 Sept. 2010- Why stunting matters_1.pdf

5. Badham J, Sweet L. Stunting: an overview. Sight Life. 2010;3:40-7.

6. World Health Organization (WHO). Complementary feeding: report of the global consultation. Geneva; 2001. 
7. Dewey K, Begum K. Long-term consequences of stunting in early life. Matern Child Nutr. 2011;7:5-18.

8. Reyes H, Perez-Cuevas R, Sandoval A, Castillo $R$, Santos J, Doubova $S$, et al. The family as a determinant of stunting in children living in conditions of extreme poverty: a case control study. BMC Public Health. 2004;4:57.

9. Yulidasari F. MP-ASI sebagai faktor risiko kejadian stunting pada anak usia 6-24 bulan di Kota Yogyakarta. Universitas Gadjah Mada; 2013.

10. Paudel R, Pradhan B, Wagle RR, Pahari DP, Onta SR. Risk factors for stunting among children: a community based case control study in Nepal. Kathmandu Univ Med J (KUMJ). 2011;10:18-24.

11. Kementerian Kesehatan Republik Indonesia. Petunjuk pelaksanaan surveilans gizi. Jakarta: Kementerian Kesehatan RI; 2012.

12. World Health Organization (WHO). Indicators for assessing infant and young child feeding practices. Washington DC: WHO; 2007.

13. Adriani M, Wiratjamadi B. Pengantar gizi masyarakat. Jakarta: Kencana Prenada Media Group; 2012.

14. Kramer MS, Kakuma R. Optimal duration of exclusive breastfeeding. Cochrane database of systematic reviews (Online). Geneva: WHO; 2001.

15. Gupta N, Gehri M, Stettler N. Early introduction of water and complementary feeding and nutritional status of children in Nothern Senegal. Public Health Nutr. 2007;10(11):1299-304.

16. Victora $C, M$ de $O$, Hallal P, Blossner M, Shrimpton R. Worldwide timing of growth faltering: revisiting implications for interventions. Pediatrics. 2010; 125 (3): e473-80.

17. Marriot $P$, White A, Hadden L, Davies J, Wallingford J. World Health Organization (WHO) infant and young child feeding indicators: association with growth measures in 14 low-income countries. Matern Child Nutr. 2011;8(3):354-70.

18. Rah J, Akhter N, Semba R, de Pee S, Bloem M, Campbell $A$, et al. Low diversity is a predictor of child stunting in Rural Bangladesh. Eur $\mathrm{J}$ Child Nutr. 2010;64:1393-8.

19. Arimond M, Ruel M. Dietary diversity is associated with child nutritional status: evidence from 11 demographic and health surveys. J Nutr. 2004;134:2579-85.

20. Onyango A, Koskia K, Tuckerb K. Food diversity versus breastfeeding choice in determining anthropometric status in rural Kenyan toddlers. Int J Epidemiol. 1997;27:484-9.

21. Steyn N, Nel J, Nantel G, Kennedy G, Labadarios D. Food variety and dietary diversity scores in children: are they good indicators of dietary adequacy? Public Health Nutr. 2005;9(5):64450.

22. Kennedy G, Pedro M, Seghieri C, Nantel $\mathrm{G}$, Brouwer I. Dietary diversity score is a useful indicator of micronutrient intake in non-breast-feeding Filipino children. J Nutr. 2007;137:472-7.

23. Moursi M, Arimond M, Dewey K, Tre'che S, Ruel M, Delpeuch F. Dietary diversity is a good predictor of the micronutrient density of the diet of 6- to 23-month-old children in Madagascar. J Nutr. 2007;138:2448-53.

24. Daniels M, Adair L, Popkin B, Truong Y. Dietary diversity scores can be improved through the use of portion requirements: an analysis in young Filipino children. Eur J Clin Nutr. 2009;63:199-208.

25. Sawadago P, Martin-Pre' vel Y, Savy M, Kameli $Y$, Traissac P, Traore'An, et al. Infant and child feeding index is associated with the nutritional status of 6- to 23-month-old children in rural Burkina Faso. J Nutr. 2006;136:656-63.

26. Umeta M, West C, Verhoef H, Haidar J, Hautvast J. Factors associated with stunting in infants aged 5-11 months in the Dodota-Sire district, rural Ethiopia. J Nutr. 2003;133:1064-9.

27. Soetjiningsih, Suandi I. Gizi untuk tumbuh kembang anak. Jakarta: Sagung Seto; 2008.

28. Dewey K, Adu-Afarwuah S. Systematic review of the efficacy and effectiveness of complementary feeding interventions in developing countries. Matern Child Nutr. 2008;4:24-85. 
29. Branca F, Ferrari M. Impact of micronutrient deficiencies on growth: the stunting syndrome. Ann Nutr Metab. 2002;46 Suppl 1:8-17.

30. Marquis G, Habicht J, Lanata C, Blacak R, Rasmusse K. Breastmilk or animalproductfoods improve linear growth of peruvian toddlers consuming marginal diets. Am J Clin Nutr. 1997;66:1102-9.
31. Amigo H, Buston P, Sun K, Akhter N, Bloem M. Is there are relationship between parent's short height and their children's? social interclass epidemiologic study. Rev Med Chil. 1997;125(8): 863-8.

32. Barker D, Godfrey K. Gizi ibu, programming janin, dan penyakit kronis dewasa. Gizi kesehatan masyarakat. Jakarta: Penerbit Buku Kedokteran EGC; 2005. p. 372-90. 